\title{
The Effect of Water Vapor Originating from Land on the 2018 Drought Development in Europe
}

\author{
Fares Al Hasan ${ }^{1, *}$, Andreas Link ${ }^{2}$ and Ruud J. van der Ent ${ }^{1}$ (D) \\ 1 Department of Water Management, Faculty of Civil Engineering and Geosciences, Delft University \\ of Technology, 2628 CN Delft, The Netherlands; r.j.vanderent@tudelft.nl \\ 2 Sustainable Engineering, Technische Universität Berlin, 10623 Berlin, Germany; andreas.link@tu-berlin.de \\ * Correspondence: f.alhasan@tudelft.nl
}

Citation: Al Hasan, F.; Link, A.; van der Ent, R.J. The Effect of Water Vapor Originating from Land on the 2018 Drought Development in Europe. Water 2021, 13, 2856. https: / / doi.org/10.3390/w13202856

Academic Editor: Renato Morbidelli

Received: 19 July 2021

Accepted: 8 October 2021

Published: 13 October 2021

Publisher's Note: MDPI stays neutral with regard to jurisdictional claims in published maps and institutional affiliations.

Copyright: (c) 2021 by the authors Licensee MDPI, Basel, Switzerland. This article is an open access article distributed under the terms and conditions of the Creative Commons Attribution (CC BY) license (https:// creativecommons.org/licenses/by/ $4.0 /)$.
Abstract: The 2018 summer drought in Europe was particularly extreme in terms of intensity and impact due to the combination of low rainfall and high temperatures. However, it remains unclear how this drought developed in time and space in such an extreme way. In this study we aimed to get a better understanding of the role of land-atmosphere interactions. More specifically, we investigated whether there was a change in water vapor originating from land, if that caused a reduction in rainfall, and by this mechanism possibly the propagation and intensification of the drought in Europe. Our first step was to use remote sensing products for soil moisture content (SMC) and the normalized difference vegetation index (NDVI) to see where the 2018 drought started and how it developed in time and space. Our SMC and NDVI analysis showed that the 2018 drought started to impact the soil and vegetation state in June in Scandinavia and the British Isles. After that it moved towards the west of Europe where it intensified in July and August. In September, it started to decay. In October, drought was observed in Southeast Europe as well. Based on the observed patterns we divided Europe into six regions of similar spatiotemporal characteristics of SMC and NDVI. Then, we used a global gridded dataset of the fate of land evaporation (i.e., where it ends up as precipitation) to investigate whether the drought intensification and propagation was impacted by the reduction in water vapor transported from the regions that first experienced the drought. This impact was investigated by identifying the anomalies in the water vapor originating from land recycling, imports, and exports within Europe during the spring, summer, and autumn seasons. From these regions we identified four drought regions and investigated the changes in water vapor originating from source regions on the development of drought in those regions. It was found that during the onset phase of the 2018 drought in Europe that the water vapor originating from land played an important role in mitigating the precipitation anomalies as, for example, the share of land evaporation contributing to precipitation increased from $27 \%$ (normal years) to $38 \%$ (2018) during July in the west of Europe. Land evaporation played a minor role in amplifying it during the intensification phase of the drought as the share of land evaporation contribution to precipitation decreased from $23 \%$ (normal years) to $21 \%$ (2018) during August in the west of Europe. These findings are somewhat in contrast to similar studies in other continents that found the land surface to play a strong amplifying role for drought development. Subsequently, we found that the relative increase in the amount of land water vapor originating from eastern half of Europe played a role in delaying the onset and accelerating the decay of the 2018 drought in the west of Europe.

Keywords: drought; NDVI; soil moisture; moisture recycling; land-atmosphere interactions

\section{Introduction}

Increase in the frequency and intensity of drought events and their catastrophic effects on many life aspects is a matter of growing concern [1]. An example of a recent severe and impactful drought is that of 2018 in Europe [2,3]. During spring, summer and autumn of 2018 in Europe, the temperatures were much higher than average and the rainfall rates were 
much lower than normal which created favorable conditions for the emergence of extreme drought [4]. Bakke et al. [5] related the development of extreme meteorological drought in Northern and part of Central Europe during the summer of 2018 to the high-pressure system over the North Sea and the low-pressure system over Greenland and Russia. The frequency of such an extreme drought event will become higher because of climate change and it is expected the drought of 2018 could become common occurrence around 2043 [4]. A poorly understood aspect of extreme drought events, such as the 2018 drought in Europe, is the role of land-atmosphere interactions, and more specifically the role of anomalies in water vapor originating from land [6].

Droughts can be monitored in time and space making use of remote sensing observations. When focusing on agricultural and vegetation drought, soil moisture and NDVI are among the most important satellite observations that can be used to detect and to monitor large-scale drought events [7-13]. Whereas the remote sensing observations reveal spatiotemporal patterns of drought development, they do not give direct information about the processes. Studies have indicated that the large scale droughts events tend to get displaced from their origins to other areas, and in some cases these displacements amounted to several thousand kilometers [14,15]. For example, Herrera-Estrada et al. [14], using a Lagrangian approach, found that about $10 \%$ of the drought events that took place between 1979 and 2009 in North America had been displaced more than $500 \mathrm{~km}$ from their origins.

The process responsible for drought displacement is thought to be the lack of atmospheric moisture transport caused by a reduction of evaporation from upwind regions, and similarly the same process could cause drought intensification when moisture sources are mainly local [16-18]. Herrera-Estrada et al. [16] found that the lack of upwind water vapor originating from land was responsible for about $62 \%$ of the rainfall shortage in downwind regions during the 2012 Midwest drought event in the USA. Similarly, Schumacher et al. [17] found that the lack of soil moisture in upwind regions was behind increasing the sensible heat advection to downwind regions by 30\% during the 2003 and 2010 mega heatwave events in Europe. Holgate et al. [18] found that the water vapor originating from land played a role in exacerbating the precipitation anomalies, although this role is minor with up to $6 \%$ during three drought events that occurred in southeast Australia between 1981 and 2011.

Benedict et al. [19] studied the moisture sources of the Rhine basin in Europe during the dry summers of 2003 and 2018 and did not find an important role for the land. They found that the reduction in the amount of transported water vapor originating from the ocean was behind the development of the extreme droughts. They also concluded that the change in the regional and imported water vapor from source regions to Rhine basin resulted mainly from change in wind directions and not because of the change in the amount of water vapor originating from source regions. However, the complete development in time and space of the extreme drought over the European continent in 2018 and the role of anomalies in water vapor originating from the land is still unclear.

The aim of this paper is to better understand the role of water vapor transport anomalies originating from land evaporation on the onset, intensification, propagation, and displacement of the 2018 drought event in Europe. Moreover, if reduced water vapor transport originating from land is found to play a role in causing reduced precipitation we want to know if (1) this is caused by reduced regional and upwind land evaporation with the general source region for precipitation being rather stable, or (2) this is caused by changes in moisture transport direction leading to different precipitation source regions. First we will, however, make a spatiotemporal analysis of the 2018 drought development using two of the most popular drought indicators derived from satellite imagery, which are soil moisture content (SMC) [20] and the normalized difference vegetation index (NDVI) [8] We will use these indicators to group regions in Europe that experienced similar drought development (see Section 3.1). After that, we will analyze the evaporation export and precipitation import—or regional recycling —of atmospheric moisture for these regions under 
normal conditions and for the anomalous 2018 case making use of gridded source-sink relationships of atmospheric water vapor [21] (see Section 3.2). The findings of this study will provide more clarity on the significance of water vapor transport from upwind and local land regions to downwind regions on the dampening or amplification and propagation of a drought event.

\section{Materials and Methods}

\subsection{Study Area and Time Span}

We studied the domain that lies between $11^{\circ} \mathrm{W}-32^{\circ} \mathrm{E}$ and $34-73^{\circ} \mathrm{N}$ (see Figure 1). Although this does not correspond exactly with Europe from a geographical sense, we will still refer to this domain as Europe for simplicity. We focus our analysis on the months May to October, because these were the driest months [22] and use the years 2000-2018 as a baseline based on data availability.

\subsection{Remote Sensing Based Drought Indicators}

For observing the drought, we aimed to avoid indicators based on modelling, but chose more direct observations derived from remote sensing which are soil moisture content (SMC) and the normalized difference vegetation index (NDVI). SMC was obtained from the ESA CCI SM v04.7 product, which was generated from active and passive microwave space borne instruments [23-25]. This product is regarded as the best in estimating SMC and capturing the changes that connected with drought [7]. This product is regarded to provide information about the amount of water present in approximately the top $5 \mathrm{~cm}$ of the soil. The data of this product was downloaded for the period from 2002-2018.

In general, one would expect the vegetation to have a delayed response compared to SMC in drought development. As such, vegetation indices derived from satellite observation are useful to monitor the extent and severity of drought events [10]. The monthly NDVI was obtained from the Monthly L3 global $0.05^{\circ}$ Modis Terre Vegetation indices product [26]. The data of this product was downloaded for the period 2000-2018. SMC and NDVI time series were used to generate ranking percentile maps of the 2018 situation over Europe by using the following expression:

$$
C_{i, 2018}=\frac{R_{i, 2018}}{N+1} \times 100,
$$

where, $C_{i, 2018}$ is the calculated ranking percentile for the year 2018 in the month $i . R_{i, 2018}$ is the rank of the data point in the time series of that month $i . N$ is the number of years (17 years for SMC and 19 years for NDVI). Based on analyzing the SMC and NDVI ranking percentile maps Europe was divided into different regions through a visual inspection of similarity in terms of timing and spatial extent of the drought. For these regions we computed the ranking percentiles of average SMC and average NDVI per region. We divided the percentile bar into 3 equal parts and categorized it into 'Dry', 'Normal' and 'Wet'. We classified a month as dry month when the SMC ranking percentiles of average of that month and the NDVI ranking percentiles of the average of the following month are both less than 33.4. 
a

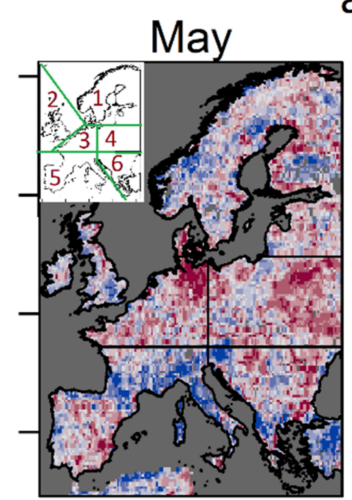

Jul

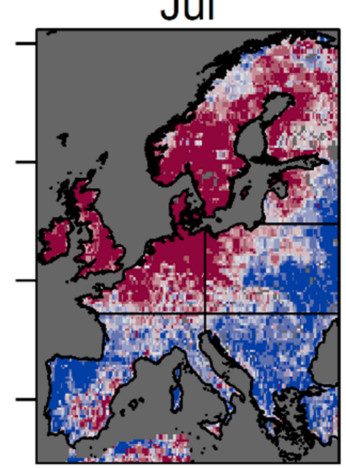

Sep

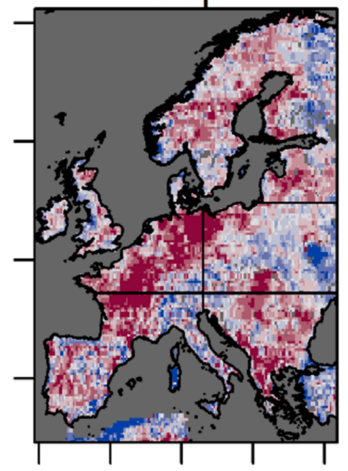

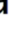

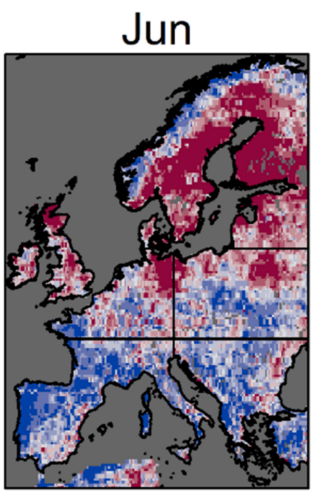

Aug

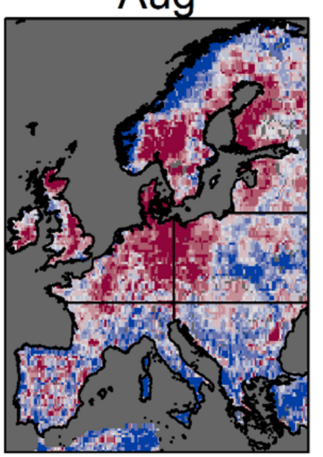

Oct

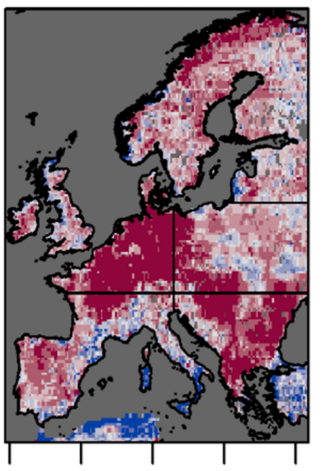

b

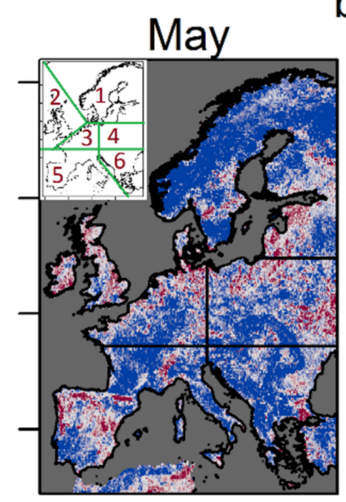

Jul

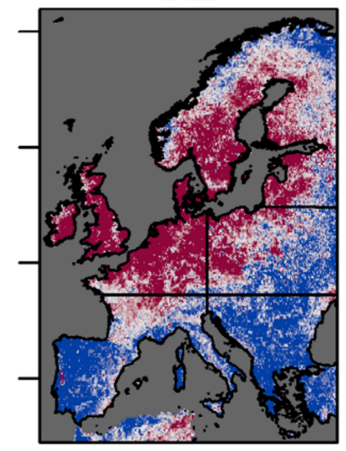

Sep
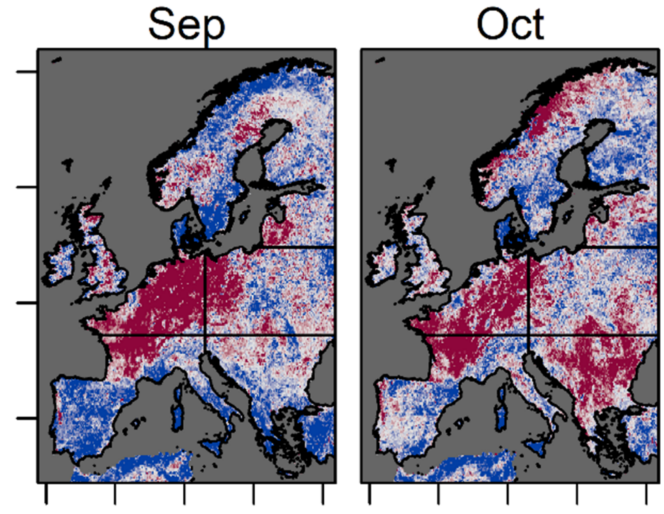

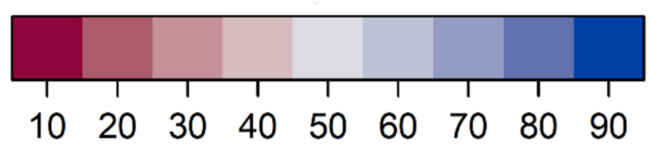

Figure 1. The development of the 2018 drought in Europe from remote sensing data. (a) SMC ranking percentiles and (b) NDVI ranking percentiles (Equation (1)). The numbers in the upper left corners of $(\mathbf{a}, \mathbf{b})$ indicate regions that were grouped for similar drought development characteristics. Region 1 (Scandinavia and Baltic), region 2 (British Isles), region 3 (west of Europe), region 4 (east of Europe), region 5 (southwest Europe) and region 6 (Southeast Europe), consecutively.

\subsection{Total Evaporation and Precipitation Anomalies}

We obtained evaporation and precipitation data for the period 2000 to 2018 from the ERA-Interim reanalysis data [27] for consistency with the atmospheric water vapor sourcesink dataset (see Section 2.4). Precipitation $P$ and evaporation $E$ anomalies were calculated for each region to be able to compare between land evaporation export and precipitation originating from land import anomalies with the total evaporation and precipitation anomalies. We used the following expression to calculate the anomalies:

$$
\Delta \mathrm{z}_{i, 2018}=z_{i, 2018}-\overline{z_{i}},
$$


where, $z$ represents $P$ or $E$, respectively, $z_{i, 2018}$ is the value in month $i\left(\mathrm{~mm} \mathrm{month}{ }^{-1}\right)$ and $\overline{z_{i}}$ is the climatology of that month based on the 19 years of data (2000-2018).

\subsection{Anomalies in Import and Export of Water Vapor Originating from Land}

We used the fate of land evaporation dataset by Link et al. [21]. This dataset has $1.5^{\circ}$ resolution and was generated by running the Water Accounting Model 2-layers (WAM2layers) with ERA-Interim reanalysis data [27]. WAM-2layers is an Eulerian atmospheric water vapor tracking model that tracks the flow of water from source (evaporation) to sink (precipitation), based on 3-dimensional wind speeds and specific humidity [28]. The fate of land evaporation dataset covered the period 2000-2018. WAM-2layers is a state-ofthe-art moisture tracking model that was validated against a regional climate model with moisture tracking capabilities [29] and has been used broadly with different underlying climate datasets answering a wide array of research questions [30-35]. The specific dataset we used here [21] provides readily available moisture source-receptor relations globally without the need of running moisture tracking again and has found first applications besides this work [36]. These source-receptor relations were found to be similar compared to another recent dataset [37]. We spatially resampled the data to high resolution around the coast by considering the exact shape of coastline and as such dividing oceanic and land contributions.

This dataset was used to detect the anomalies in atmospheric water vapor import and export or regional recycling from land from May to October 2018 by calculating evaporation export and precipitation import ratios. The ratio of water vapor that originated from source region $x$ and fell in sink region $y$ in month $i$ and year(s) $j$ is called the evaporation export ratio:

$$
\varepsilon_{i, j(x \rightarrow y)}=\frac{E_{i, j(x \rightarrow y)}}{E_{i, j(x)}},
$$

where $E_{i, j(x \rightarrow y)}$ is the evaporation that was exported from region $x$ to region $y$ and $E_{i, j(x)}$ is the total evaporation from region $x$ both during month $i$ and year(s) $j$. Similarly, we can define the precipitation import ratio:

$$
\rho_{i, j(x \rightarrow y)}=\frac{P_{i, j(x \rightarrow y)}}{P_{i, j(y)}}
$$

where it should be noted that $P$ is now defined in the sink region $y$. When $x$ is equal to $y$, the ratios in Equations (3) and (4) can be referred to as the regional evaporation recycling ratio and the regional precipitation recycling ratio, respectively, instead [38].

The relative difference was computed to assess the role of anomalies in land evaporation supplies during the 2018 drought with the following expression:

$$
\Delta P_{i, \text { rel }(\mathrm{x} \rightarrow \mathrm{y})}=\frac{P_{i, 2018(x \rightarrow y)}-P_{i, M(x \rightarrow y)}}{P_{i, M(x \rightarrow y)}},
$$

where subscript $M$ stands for the climatology period of 2000-2018, and note that $P$ is always expressed as a flux with dimension of [length or volume $\times$ time $^{-1}$ ]. Note that in Equations (3)-(5) the evaporation exports $E_{i, j(x \rightarrow y)}$ are the same as the precipitation imports $P_{i, j(x \rightarrow y)}$ in case they are expressed as a [volume $\times$ time $^{-1}$ ].

\section{Results and Discussion}

\subsection{Spatiotemporal Drought Development from Remote Sensing Observations}

We used the calculated SMC percentile map and calculated NDVI percentile map (Figure 1) to detect and monitor the development of the 2018 drought in Europe. The SMC and NDVI ranking percentile maps showed that the drought started in June with low SMC (Figure 1a) in the north of Europe (Scandinavia and Baltic) and on the British Isles. After that the drought started to affect the vegetation status (Figure $1 \mathrm{~b}$ ) and to expand towards 
the west and the center of Europe in July and August. In September, drought appeared in Southeast Europe. Whereas SMC appears to slightly recover in the west of Europe in October, NDVI remains anomalously low.

Based on a visual analysis of Figure 1, we looked at similar spatiotemporal zones in terms of NDVI and SMC signature and as such divided Europe into six regions. Regions 1 (Scandinavia and Baltic) and 2 (British Isles) experienced drought in June and July, and started to recover in August. In region 3 (west of Europe) the drought was the most severe and lasted from July until October. Region 4 (east of Europe) and 5 (Southwest Europe) did not experience a significant drought. Region 6 (Southeast Europe) only experienced drought in September and October. Further analysis focuses on the drought regions only (region 1, 2, 3, and 6).

The first question in this study sought to determine the development of the 2018 drought in Europe in terms of intensity and spatial extension. As can be seen from the maps in Figure 1, the spatial extent of the 2018 drought was large (about two-thirds of Europe). It also can be seen from Figures 1 and 2 that the intensity of the 2018 drought had varied between regions (the most intense drought period was registered in region 3). Our maps also show possible relations between the drought in regions 1, 2, 3 and 6 in terms of spatial and temporal connection. However, we further studied the role of water vapor to confirm or reject possible links between those different drought regions.

a

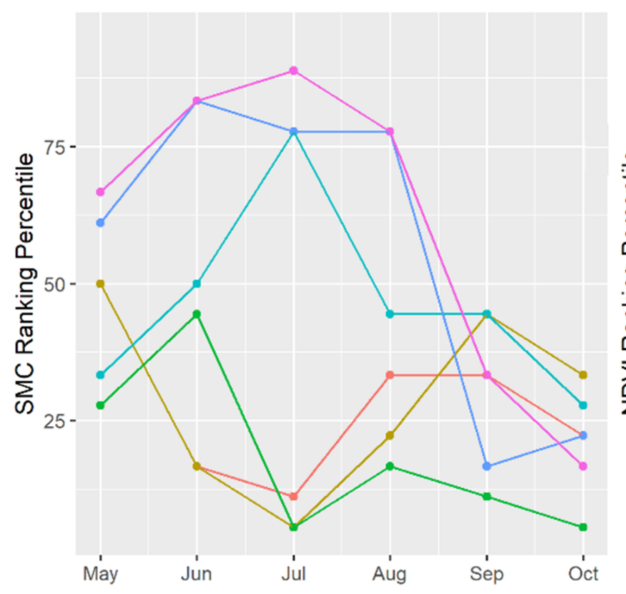

b

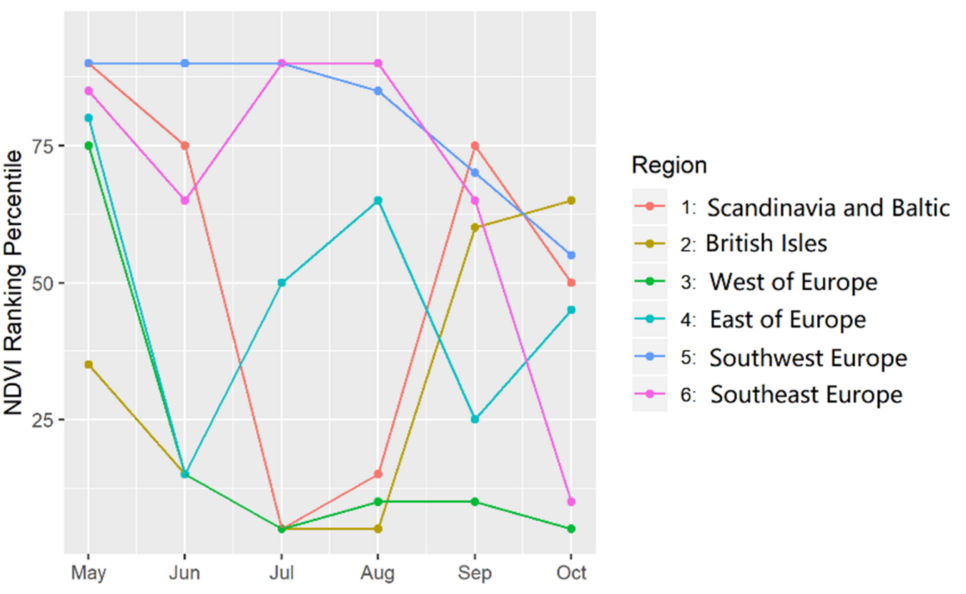

Figure 2. Region average development of (a) SMC and (b) NDVI in 2018. The spatial extent of the regions is shown in Figure 1.

\subsection{The Role of Atmospheric Moisture Originating from Land in Drought Development 3.2.1. Evaporation and Precipitation Anomalies}

Figure 3 provides an overview of the evaporation and precipitation anomalies during May-October of 2018 for each region. These values are necessary to be able to interpret further results about water vapor recycling and transport anomalies (Sections 3.2.2 and 3.2.3). In addition, these values confirm what we saw from the SMC and NDVI analysis (Figures 1 and 2), namely that region 1 and 2 experienced extreme drought in terms of precipitation anomalies from May until July. Moreover, region 3 had anomalously low precipitation from July until October, but interestingly, evaporation was initially higher than average until the soil and vegetation were affected, and the evaporation anomalies also turned negative: in June for region 1, in July and August for region 2, and from July until October for region 3. Finally, region 6 experienced negative precipitation anomalies in September and October and the evaporation anomalies turned negative in October. Overall, region 3 experienced the biggest monthly reduction in precipitation (about $40 \mathrm{~mm} \mathrm{month}^{-1}$ in July) and evaporation (about $17 \mathrm{~mm}$ month $^{-1}$ in August). 
a

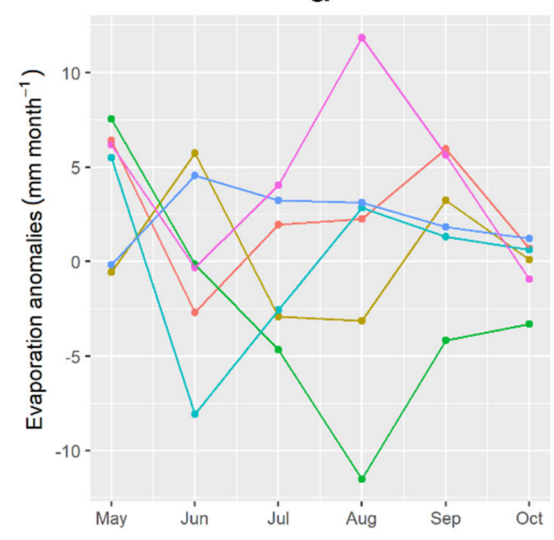

b

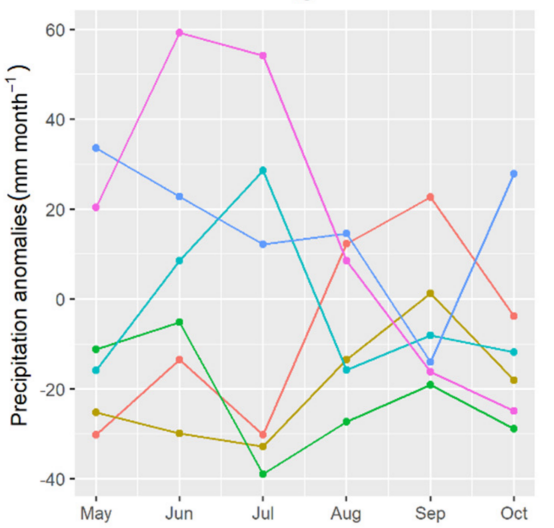

Region

$\rightarrow$ 1: Scandinavia and Baltic

$\rightarrow$ 2: British Isles

$\rightarrow$ 3: West of Europe

$\rightarrow$ 4: East of Europe

$\rightarrow$ 5: Southwest Europe

$\rightarrow$ 6: Southeast Europe

Figure 3. Region average development of (a) evaporation and (b) precipitation anomalies in 2018. The total numbers of normal and 2018 evaporation and precipitation can be found in the Supplementary Materials (Tables S1-S4). The spatial extent of the regions is shown in Figure 1.

3.2.2. Evaporation Export and Precipitation Import between Land and Drought Regions, Recycling within Regions and Transport between Regions

The aim of calculating the evaporation export and precipitation import ratios was to assess the role of transported land evaporation that emerged from different land source regions in drought development of each drought region (Figures 4-6). When both the 2018 evaporation export ratio (dark red line) is below the normal evaporation export ratio (orange line) and the 2018 precipitation import ratio (dark blue line) is below the normal precipitation import ratio (cyan line) this should be interpreted as an amplifying effect on the drought. Conversely, if the 2018 precipitation import is above the normal precipitation import ratio this should be interpreted as a dampening effect on the drought (Figures 4-6). However, the interplay is complicated as total precipitation and evaporation also deviate (Figure 3). In Figures 3-6 it can be observed that:

- In region 1 (Scandinavia and Baltic) and during its drought period (yellow background) the exported evaporation from land (sum of contributions from region 1 to 6 ) to this region reported the highest percent point reductions in June (from $49 \%$ to $25 \%$ ) and July (from 53\% to 23\%) (Figure 4), related mostly to reductions in evaporation recycling (Figure 5), but also from region 2-5 (Figure 6). This reduction in evaporation export ratio led to reduce the precipitation import ratio from land to this region (from $30 \%$ to $22 \%$ in June and from $32 \%$ to $24 \%$ in July). Overall, we can conclude that the drought in region 1 was somewhat amplified by the reduction in the evaporation export ratios from land to this region during June (mainly regional (Figure 5)) and in July (mainly from region 3 (Figure 6)) of 2018.

- In region 2 (British Isles) and during its drought period (yellow background), the precipitation import ratio from land experienced an increase in June (from $12 \%$ to $22 \%$ ) while it experienced a small decrease in July (from 9\% to 7\%) (Figure 4), which was also the case for regional precipitation recycling (from 5\% to 7\% in June and from 4.5 to $4 \%$ in July) (Figure 5). Conversely, there was a minor decrease in the evaporation export ratio from land in June (from $7 \%$ to $6 \%$ ) and July (from $6 \%$ to $3 \%$ ). We can conclude that in June the land surface through the increase in precipitation import/recycling ratios, despite the small decrease in the evaporation export/recycling ratios, helped in dampening the total precipitation anomalies. In July, the small decrease in the precipitation import and evaporation export ratios (Figures 4-6) led to amplify the drought conditions in this region. However, this amplification role is still minor in comparison with the total evaporation and precipitation anomalies (Figure 3).

- In region 3 (west of Europe) and during its drought period (yellow background), the precipitation import ratio from land increased in July (from 27\% to 38\%) (Figure 4) as did the regional precipitation recycling ratio (from 12\% to 18\%) (Figure 5) while 
the evaporation recycling ratio slightly decreased (from $8 \%$ to $7 \%$ ) during this month (Figure 5). In August all land import/export (Figure 4) as well as regional recycling (Figure 5) ratios decreased slightly whereas total evaporation and precipitation were also at a minimum (Figure 3). During September and October, the precipitation import ratio experienced a small increase (about 2 percent points). We conclude that the drought in this region was first dampened by land-atmosphere interactions during July and then slightly amplified during August by the lack of imported (mainly region 2, (Figure 6)) and recycled water vapor (Figure 5) and then slightly dampened again during September and October (mainly regions 4-6, (Figure 6)).

- In region 6 (Southeast Europe) and during its drought period (yellow background), the precipitation import ratio increased in September (from 25\% to 31\%), which can mainly be attributed to an increase in regional recycling (Figure 5) and thus dampening of the drought. In October there was little change in any of the ratios (Figures 4-6). We can conclude that this drought event was rather disconnected from the other drought regions as the anomalies in water vapor contribution from the other regions were very small (Figure 6).
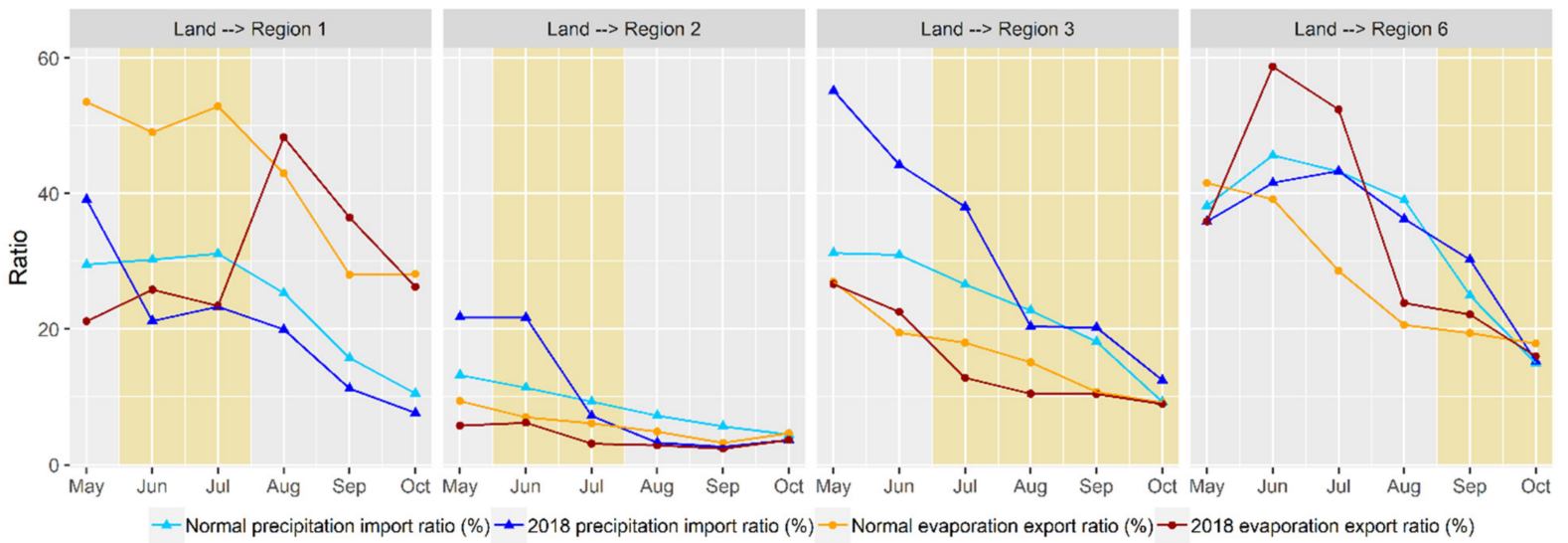

Figure 4. The 2018 monthly evaporation export and precipitation import ratios (Equations (3) and (4)) with land being the source region while drought regions 1,2, 3 and 6 are being the sink regions. The location of these regions is indicated in Figure 1. A yellow shading is applied when the month experiences drought (i.e., SMC of that month and NDVI of the following month percentiles $<33.4$ ). Note, regions 4 and 5 did not experience a strong drought (Figures 1-3) and were, therefore, not included here.
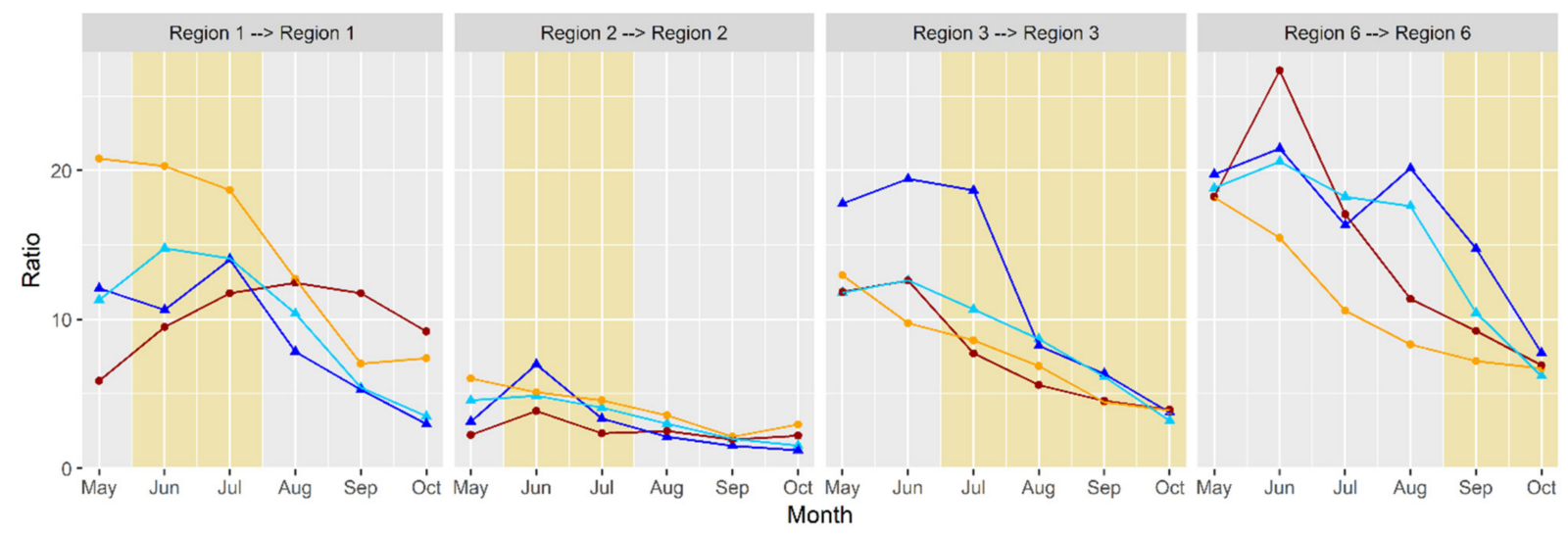

$\rightarrow 2018$ evaporation recycling ratio $(\%) \rightarrow-2018$ precipitation recycling ratio $(\%) \rightarrow-$ Normal evaporation recycling ratio $(\%) \rightarrow-$ Normal precipitation recycling ratio $(\%)$

Figure 5. The 2018 monthly regional evaporation and precipitation recycling ratios (Equations (3) and (4)) of the drought regions 1, 2, 3 and 6 . The location of these region is indicated in Figure 1. A yellow shading is applied when the month experiences drought (i.e., SMC of that month and NDVI of the following month percentiles <33.4). Note, regions 4 and 5 did not experience a strong drought (Figures 1-3) and were, therefore, not included here. 


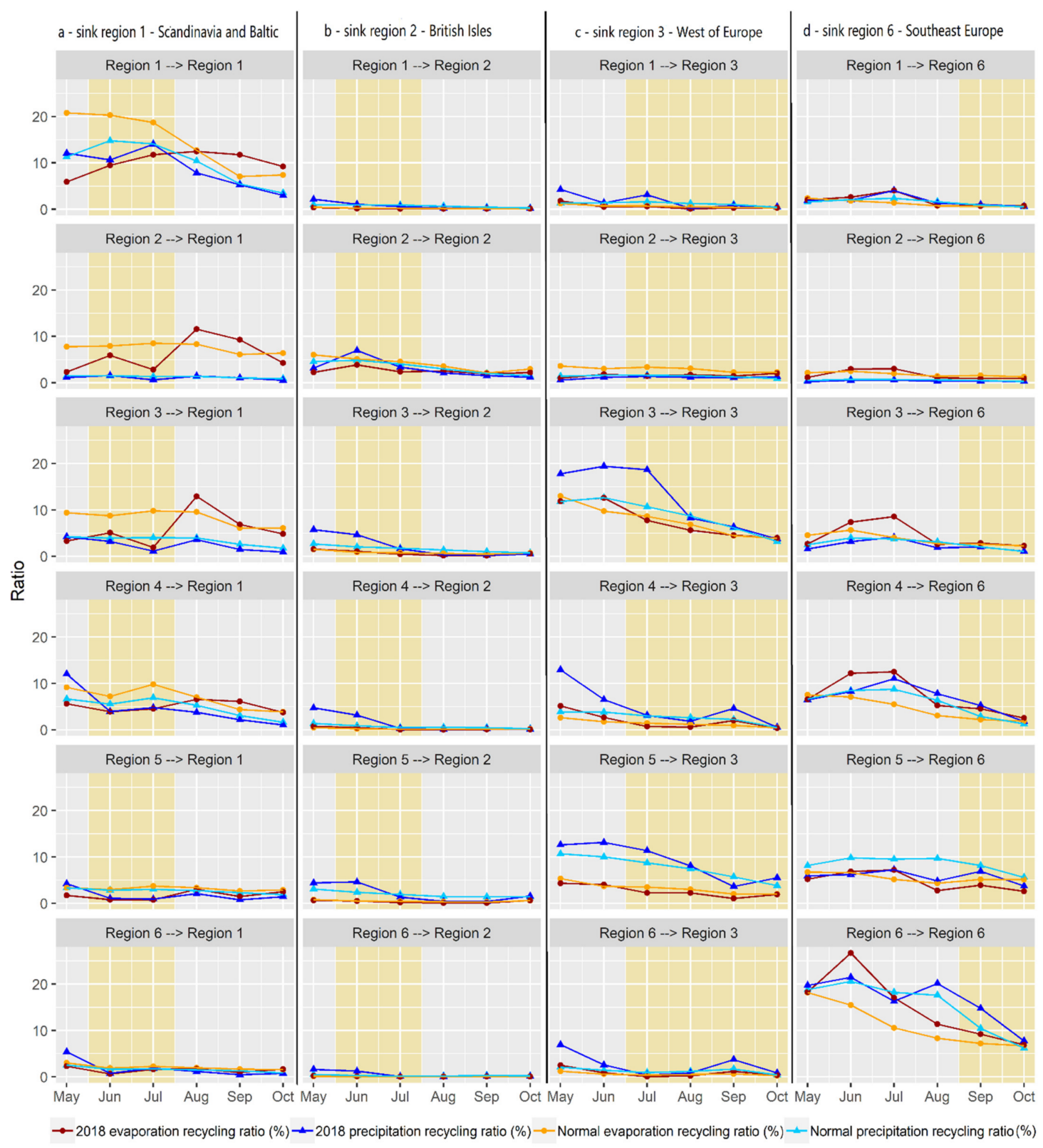

Figure 6. The 2018 monthly evaporation export and precipitation import ratios of (a) regions 1 (b) region 2, (c) region 3 and (d) region 6 in comparison with the climatology (2000-2018) of monthly evaporation export and precipitation import ratios. A yellow shading is applied when the month experiences drought (i.e., SMC of that month and NDVI of the following month percentiles <33.4). The location of the regions is given in Figure 1.

\subsubsection{Case Study West of Europe}

Since region 3 experienced the most extreme drought of all regions (Figures 1-3) and seemed to be influenced by land evaporation most (Figures 4-6) it was analyzed in more detail. In general, we saw that the intensity of the 2018 drought was dampened in July and amplified slightly in August by regional and transported land evaporation (Figures 4-6). However, it is still not clear what happened exactly to the sources of moisture that supply it to this region during the 2018 drought.

Figures 7 and 8 present the changes that happened to the land evaporation originating from source regions and fell in sink region 3. Usually in May, region 2, region 3 itself and region 5 are the main sources of moisture; however, during May of 2018 the amount of moisture originating from source regions 2, 3 and 5 reported significant reduction (about $50 \%$ in average) while it reported significant increase from regions 1 and 4 (about $100 \%$ on 
average). In June and July, the amount of water vapor from all source regions experienced significant reduction (about 50\% in average). This reduction continued in August only for regions 1, 4, and 6 while the amount of moisture originating from source regions 2, 3, and 5 came back to the normal supply rate. In September, the amount of moisture originating from region 1, 4 and 6 increased again (about $100 \%$ on average) while the rest of source regions did not report any changes. In October, the supply of moisture from all source regions was slightly below normal.
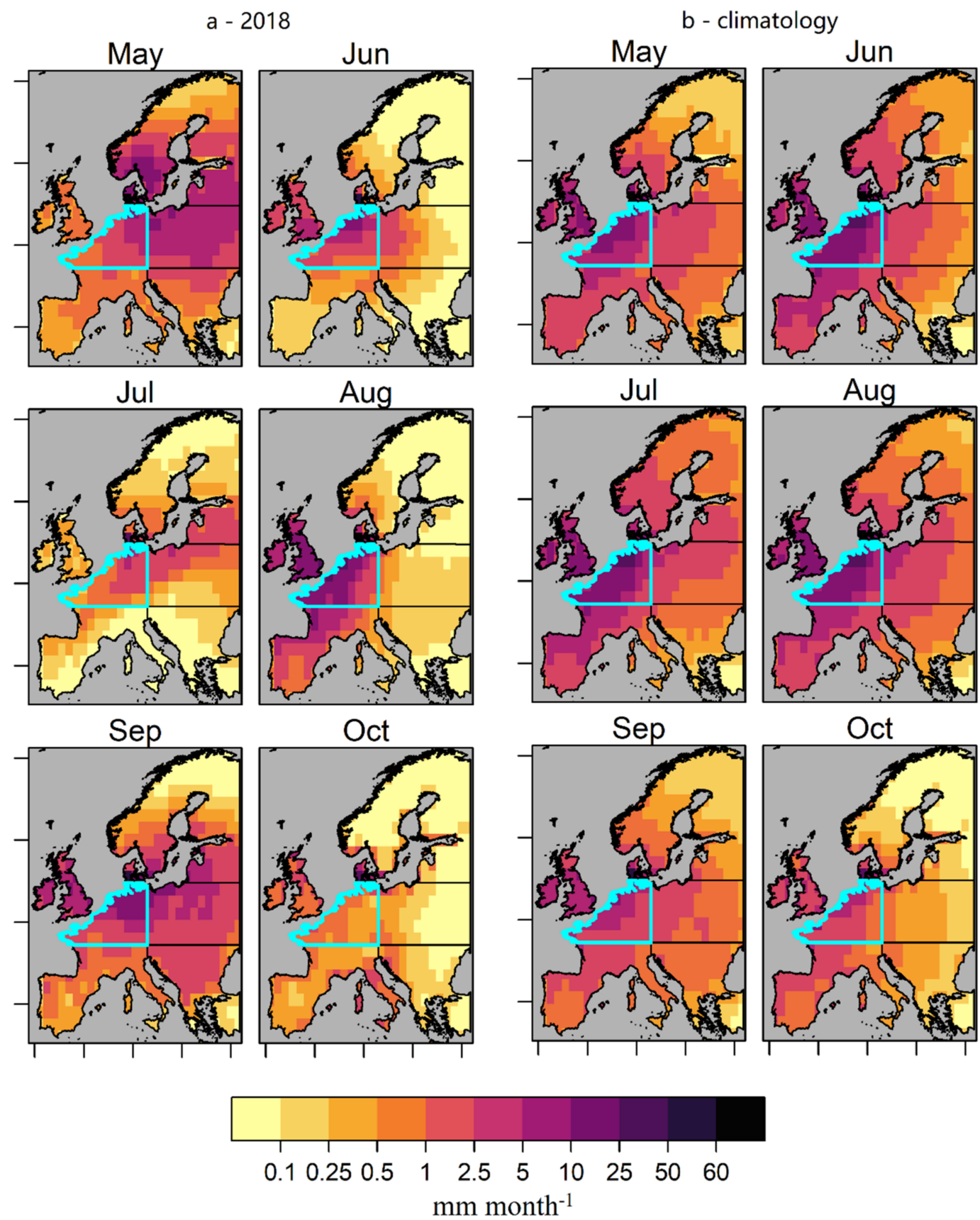

Figure 7. (a) Monthly land evaporation emerging from source regions and falling in sink region 3 in 2018 (west of Europe). (b) The climatology monthly land evaporation emerging from source regions and falling in sink region 3 (cyan outlined). 

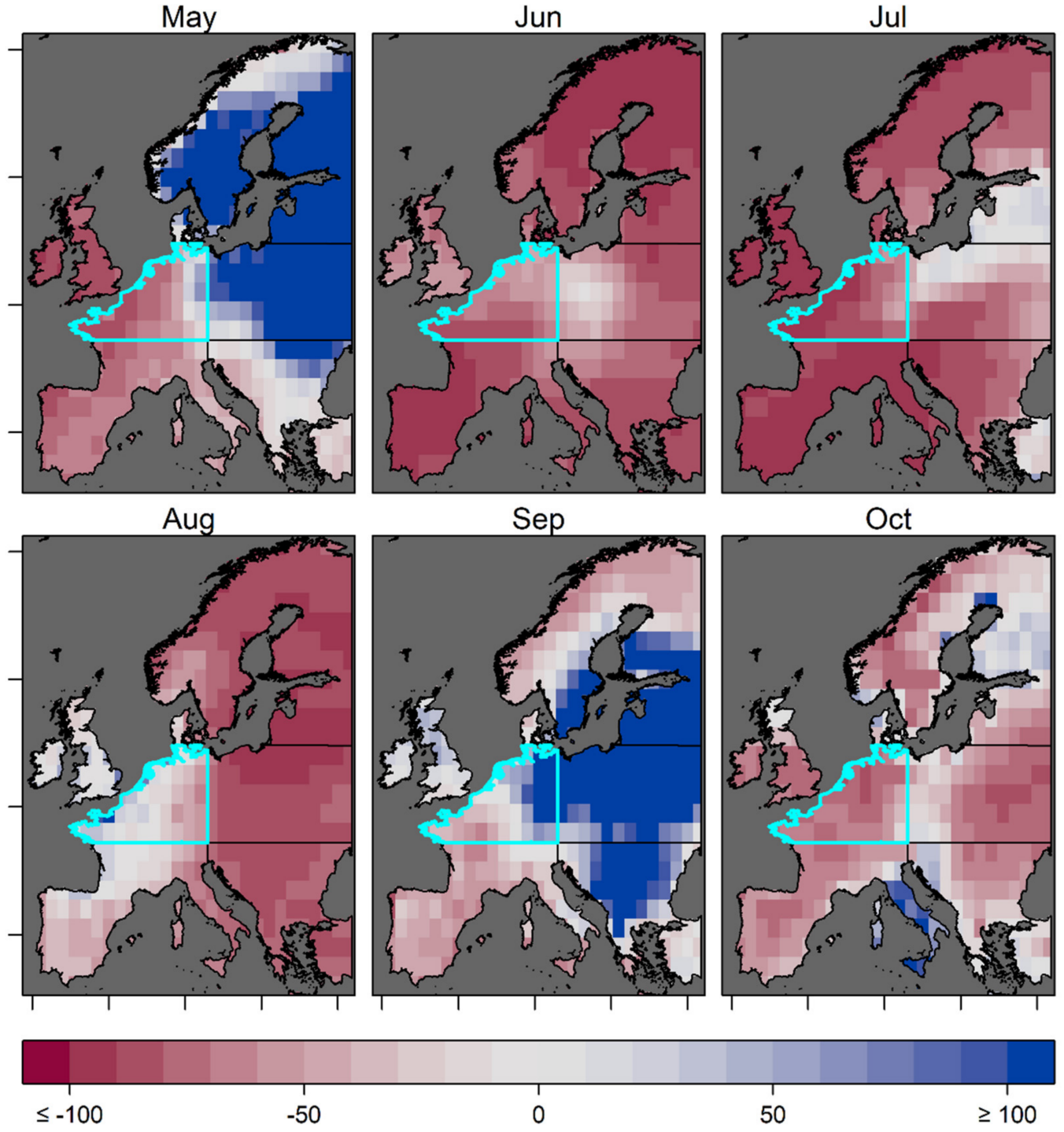

Figure 8. The 2018 monthly difference in land evaporation originating from source regions and falling in sink region 3 (cyan outlined) (Equation (5)), expressed as percentage).

These results show that the significant increase in the amount of water vapor from region 1 and 4 in May could be behind the late onset of the 2018 drought in region 3 until July where these regions compensated the lack of regional and transported water vapor that originated from the usual sources. On the other hand, the increase in the amount of water vapor originating from source regions 1, 4, and 6 in September provided some relief to the drought situation, whereas these regions added additional water vapor compared to the normal supply rate (Figures 7 and 8 ).

The results of this study show that the significant reduction in the amount of water vapor originating from land in July was not necessarily related to reduced total evaporation (Figure 3), but mainly due to a change in moisture sources from the west to the northeast (Figures 7 and 8). Conversely, in August the usual strong moisture sources from the region itself and from the British Isles were present (Figures 7 and 8), but evaporation was not as strong as normal (Figure 3), thus slightly amplifying the 2018 drought.

\section{Conclusions}

The aim of this paper was to better understand the role of water vapor transport anomalies originating from land evaporation on the development of the 2018 drought event in Europe. First, we made a spatiotemporal analysis of the 2018 drought development 
using soil moisture content (SMC) and NDVI as drought indicators (Figures 1 and 2). We found that the 2018 drought started in June with low SMC (Figure 1a) in the north of Europe (Scandinavia and Baltic region) and on the British Isles. After that the drought started to affect the vegetation status (Figure $1 \mathrm{~b}$ ) and to expand towards the west and the center of Europe in July and August. In September, drought appeared in Southeast Europe. Whereas SMC appeared to slightly recover in the west of Europe in October, NDVI remained anomalously low. Based on these results we divided Europe into six regions with similar drought characteristics.

Next, we used a dataset of gridded source-sink relationships of atmospheric water vapor [21] to answer our main research question, whether reduced water vapor transport originating from land played a role in exacerbating the drought by causing reduced precipitation. We found that the water vapor originating from land had played an important role as land evaporative sources made up 22, 22, 39 and $30 \%$ of the total precipitation in region 1 , region 2, region 3, and region 6 (see Figure 1 for a map), respectively, during the onset of the 2018 drought. The monthly anomalies (2018 - climatology, Figure 4) were up to +10 (region 1 , May), +10 (region 2, June), +11 (region 3, July), and +5 (region 4, September) indicating drought mitigation from land evaporation rather than amplification. For the Scandinavia and Baltic regions, we found, however, that the 2018 drought was intensified by the lack of regional water vapor in June and by the lack of transported water vapor from west of Europe in July. For the British Isles, on the other hand, we found that the 2018 drought was mitigated by the stable supply of regional and transported water vapor in June and slightly amplified by the lack of regional water vapor in July. For the west of Europe we found that the small reduction in the regional and transported land evaporation from source regions to sink regions in July was not amplified by the drought in source regions during onset and drought intensification. In contrast, regional and land contributions dampened the precipitation anomalies and thus the drought development. For Southeast Europe the increase in the regional water vapor mitigated the drought intensity in this region during September. From the SMC and NDVI analysis it appeared possible that this drought in Southeast Europe was connected to the drought in the rest of Europe, but the water vapor transport analysis revealed that it was rather disconnected.

A case study for the west of Europe further revealed that in May there was a significant reduction in the supply of moisture from the British Isles, the west of Europe, and Southwest Europe, while there was significant increase in the supply from the Baltic and east of Europe. In June and July there was significant reduction in moisture supply from all source regions. In August the supply rate came back to normal for the British Isles, west of Europe, and Southwest Europe, while it experienced a significant decrease from Scandinavia and Baltic, East of Europe, and Southeast Europe. In September the supply of moisture did not experience any change from all source regions located in the western half of Europe while it increased significantly from all source regions, or part of the regions located in the eastern half of Europe. In October the supply of moisture experienced a small reduction from all source regions.

The empirical findings in this study provide a new understanding of the role of water vapor originating from land on hindering the development of the drought during the onset phase and the minor role on amplifying it during the intensification phase. For the European climate it appeared that the often-hypothesized drought intensification and propagation due to land-atmosphere feedbacks exist, but that it cannot be generalized for any drought and is more likely to be of relevance during severe drought that lasts for months. We find that this is related to the pathway of drought in the hydrological cycle from a reduction in precipitation to a lagged reduction in shallow soil moisture, deep soil moisture, and a subsequent response in transpiration.

Supplementary Materials: The following are available online at https:/ /www.mdpi.com/article/10 .3390/w13202856/s1, Table S1: 2018 monthly evaporation (mm/month), Table S2: Normal monthly evaporation (mm/month), Table S3: 2018 monthly precipitation (mm/month), Table S4: Normal monthly precipitation (mm/month). 
Author Contributions: Conceptualization, F.A.H. and R.J.v.d.E.; methodology, F.A.H. and R.J.v.d.E.; software, F.A.H., A.L. and R.J.v.d.E.; formal analysis, F.A.H. and R.J.v.d.E.; writing-original draft preparation, F.A.H. and R.J.v.d.E.; writing—review and editing, R.J.v.d.E. and A.L.; visualization, F.A.H.; supervision, R.J.v.d.E.; project administration, R.J.v.d.E.; funding acquisition, F.A.H. and R.J.v.d.E. All authors have read and agreed to the published version of the manuscript.

Funding: This research was primarily funded by the Netherlands Organization for Scientific Research (NWO), project number VidW.1154.18.038. R.J.v.d.E. also acknowledges funding from NWO project number 016.Veni.181.015.

Institutional Review Board Statement: Not applicable.

Informed Consent Statement: Not applicable.

Data Availability Statement: Soil moisture data was downloaded from ESA Climate Office [23,25]. NDVI data was downloaded from NASA EOSDIS Land Processes DAAC [26]. The fate of land evaporation dataset was downloaded from Pangea [39]. The datasets and scripts generated during the current study are available upon request from the corresponding author.

Acknowledgments: We thank Wouter Dorigo and Tracy Scanlon (TU Wien) for giving us the access to download the ESA CCI SM data (v04.5). We thank Susan Steele-Dunne for general advice during various stages of this project. We thank all reviewers for their comments that helped us to improve the manuscript.

Conflicts of Interest: The authors declare no conflict of interest. The funders had no role in the design of the study; in the collection, analyses, or interpretation of data; in the writing of the manuscript, or in the decision to publish the results.

\section{References}

1. JoSpinoni, N.; Vogt, J.V.; Naumann, G.; Barbosa, P.; Dosio, A. Will drought events become more frequent and severe in Europe? Int. J. Climatol. 2018, 38, 1718-1736. [CrossRef]

2. Schuldt, B.; Buras, A.; Arend, M.; Vitasse, Y.; Beierkuhnlein, C.; Damm, A.; Gharun, M.; Grams, T.E.E.; Hauck, M.; Hajek, P.; et al. A first assessment of the impact of the extreme 2018 summer drought on Central European forests. Basic Appl. Ecol. 2020, 45, 86-103. [CrossRef]

3. Wolff, E.; van Vliet, M.T.H. Impact of the 2018 drought on pharmaceutical concentrations and general water quality of the Rhine and Meuse rivers. Sci. Total Environ. 2021, 778, 146182. [CrossRef] [PubMed]

4. Toreti, A.; Belward, A.; Perez-Dominguez, I.; Naumann, G.; Luterbacher, J.; Cronie, O.; Seguini, L.; Manfron, G.; Lopez-Lozano, R.; Baruth, B.; et al. The Exceptional 2018 European Water Seesaw Calls for Action on Adaptation. Earth's Future 2019, 7, 652-663. [CrossRef]

5. Bakke, S.J.; Ionita, M.; Tallaksen, L.M. The 2018 northern European hydrological drought and its drivers in a historical perspective. Hydrol. Earth Syst. Sci. 2020, 24, 5621-5653. [CrossRef]

6. Miralles, D.G.; Gentine, P.; Seneviratne, S.I.; Teuling, A.J. Land-atmospheric feedbacks during droughts and heatwaves: State of the science and current challenges. Ann. N. Y. Acad. Sci. 2019, 1436, 19-35. [CrossRef] [PubMed]

7. Ford, T.W.; Quiring, S.M. Comparison of Contemporary In Situ, Model, and Satellite Remote Sensing Soil Moisture With a Focus on Drought Monitoring. Water Resour. Res. 2019, 55, 1565-1582. [CrossRef]

8. Joiner, J.; Yoshida, Y.; Anderson, M.; Holmes, T.; Hain, C.; Reichle, R.; Koster, R.; Middleton, E.; Zeng, F.W. Global relationships among traditional reflectance vegetation indices (NDVI and NDII), evapotranspiration (ET), and soil moisture variability on weekly timescales. Remote Sens. Environ. 2018, 219, 339-352. [CrossRef] [PubMed]

9. Bajgiran, P.R.; Shimizu, Y.; Hosoi, F.; Omasa, K. MODIS vegetation and water indices for drought assessment in semi-arid ecosystems of Iran. J. Agric. Meteorol. 2009, 65, 349-355. [CrossRef]

10. Peters, A.J.; Walter-Shea, E.A.; Ji, L.; Viña, A.; Hayes, M.; Svoboda, M.D. Drought monitoring with NDVI-based Standardized Vegetation Index. Photogramm. Eng. Remote Sens. 2002, 68, 71-75.

11. Zhang, G.; Su, X.; Ayantobo, O.O.; Feng, K. Drought monitoring and evaluation using ESA CCI and GLDAS-Noah soil moisture datasets across China. Theor. Appl. Climatol. 2021, 144, 1407-1418. [CrossRef]

12. Blyverket, J.; Hamer, P.D.; Schneider, P.; Albergel, C.; Lahoz, W.A. Monitoring Soil Moisture Drought over Northern High Latitudes from Space. Remote Sens. 2019, 11, 1200. [CrossRef]

13. Zhang, L.; Liu, Y.; Ren, L.; Jiang, S.; Yang, X.; Yuan, F.; Wang, M.; Wei, L. Drought Monitoring and Evaluation by ESA CCI Soil Moisture Products over the Yellow River Basin. IEEE J. Sel. Top. Appl. Earth Obs. Remote Sens. 2019, 12, 3376-3386. [CrossRef]

14. Herrera-Estrada, J.E.; Satoh, Y.; Sheffield, J. Spatiotemporal dynamics of global drought. Geophys. Res. Lett. 2017, 44, $2254-2263$. [CrossRef]

15. Lloyd-Hughes, B. A spatio-temporal structure-based approach to drought characterisation. Int. J. Climatol. 2012, 32, 406-418. [CrossRef] 
16. Herrera-Estrada, J.E.; Martinez, J.A.; Dominguez, F.; Findell, K.L.; Wood, E.F.; Sheffield, J. Reduced Moisture Transport Linked to Drought Propagation Across North America. Geophys. Res. Lett. 2019, 46, 5243-5253. [CrossRef]

17. Schumacher, D.L.; Keune, J.; van Heerwaarden, C.C.; Vilà-Guerau de Arellano, J.; Teuling, A.J.; Miralles, D.G. Amplification of mega-heatwaves through heat torrents fuelled by upwind drought. Nat. Geosci. 2019, 12, 712-717. [CrossRef]

18. Holgate, C.M.; Van Dijk, A.I.J.M.; Evans, J.P.; Pitman, A.J. Local and Remote Drivers of Southeast Australian Drought. Geophys. Res. Lett. 2020, 47, e2020GL090238. [CrossRef]

19. Benedict, I.; van Heerwaarden, C.C.; van der Linden, E.C.; Weerts, A.H.; Hazeleger, W. Anomalous moisture sources of the Rhine basin during the extremely dry summers of 2003 and 2018. Weather Clim. Extrem. 2021, 31, 100302. [CrossRef]

20. Brocca, L.; Crow, W.T.; Ciabatta, L.; Massari, C.; De Rosnay, P.; Enenkel, M.; Hahn, S.; Amarnath, G.; Camici, S.; Tarpanelli, A.; et al. A Review of the Applications of ASCAT Soil Moisture Products. IEEE J. Sel. Top. Appl. Earth Obs. Remote Sens. 2017, 10, 2285-2306. [CrossRef]

21. Link, A.; Van Der Ent, R.; Berger, M.; Eisner, S.; Finkbeiner, M. The fate of land evaporation-A global dataset. Earth Syst. Sci. Data 2020, 12, 1897-1912. [CrossRef]

22. Dry and Warm Spring and Summer / Copernicus. Available online: https://climate.copernicus.eu/dry-and-warm-spring-andsummer (accessed on 27 May 2021).

23. Gruber, A.; Scanlon, T.; Van Der Schalie, R.; Wagner, W.; Dorigo, W. Evolution of the ESA CCI Soil Moisture climate data records and their underlying merging methodology. Earth Syst. Sci. Data 2019, 11, 717-739. [CrossRef]

24. Gruber, A.; Dorigo, W.A.; Crow, W.; Wagner, W. Triple Collocation-Based Merging of Satellite Soil Moisture Retrievals. IEEE Trans. Geosci. Remote Sens. 2017, 55, 6780-6792. [CrossRef]

25. Dorigo, W.; Wagner, W.; Albergel, C.; Albrecht, F.; Balsamo, G.; Brocca, L.; Chung, D.; Ertl, M.; Forkel, M.; Gruber, A.; et al. ESA CCI Soil Moisture for improved Earth system understanding: State-of-the art and future directions. Remote Sens. Environ. 2017, 203, 185-215. [CrossRef]

26. Didan, K. MOD13C2 MODIS/Terra Vegetation Indices Monthly L3 Global 0.05Deg CMG V006. 2015, Distributed by NASA EOSDIS Land Processes DAAC. Available online: https:/ / doi.org/10.5067/MODIS/MOD13C2.006 (accessed on 11 October 2021).

27. Dee, D.P.; Uppala, S.M.; Simmons, A.J.; Berrisford, P.; Poli, P.; Kobayashi, S.; Andrae, U.; Balmaseda, M.A.; Balsamo, G.; Bauer, P.; et al. The ERA-Interim reanalysis: Configuration and performance of the data assimilation system. Q. J. R. Meteorol. Soc. 2011, 137, 553-597. [CrossRef]

28. Van Der Ent, R.J.; Wang-Erlandsson, L.; Keys, P.W.; Savenije, H.H.G. Contrasting roles of interception and transpiration in the hydrological cycle-Part 2: Moisture recycling. Earth Syst. Dyn. 2014, 5, 441-469. [CrossRef]

29. Van Der Ent, R.J.; Tuinenburg, O.A.; Knoche, H.R.; Kunstmann, H.; Savenije, H.H.G. Should we use a simple or complex model for moisture recycling and atmospheric moisture tracking? Hydrol. Earth Syst. Sci. 2013, 17, 4869-4884. [CrossRef]

30. Liu, Y.; Zhang, C.; Tang, Q.; Hosseini-Moghari, S.M.; Haile, G.G.; Li, L.; Li, W.; Yang, K.; van der Ent, R.J.; Chen, D. Moisture source variations for summer rainfall in different intensity classes over Huaihe River Valley, China. Clim. Dyn. 2021, 57, 1121-1133. [CrossRef]

31. Mu, Y.; Biggs, T.W.; Sales, F. De Forests Mitigate Drought in an Agricultural Region of the Brazilian Amazon: Atmospheric Moisture Tracking to Identify Critical Source Areas. Geophys. Res. Lett. 2021, 48, e2020GL091380. [CrossRef]

32. Benedict, I.; Heerwaarden, C.C.; Van Der Ent, R.J.; Weerts, A.H.; Hazeleger, W. Decline in terrestrial moisture sources of the mississippi river basin in a future climate. J. Hydrometeorol. 2020, 21, 299-316. [CrossRef]

33. Guo, L.; Van Der Ent, R.J.; Klingaman, N.P.; Demory, M.E.; Vidale, P.L.; Turner, A.G.; Stephan, C.C.; Chevuturi, A. Effects of horizontal resolution and air-sea coupling on simulated moisture source for East Asian precipitation in MetUM GA6/GC2. Geosci. Model Dev. 2020, 13, 6011-6028. [CrossRef]

34. Findell, K.L.; Keys, P.W.; Ent, R.J.; van der Lintner, B.R.; Berg, A.; Krasting, J.P. Rising temperatures increase importance of oceanic evaporation as a source for continental precipitation. J. Clim. 2019, 32, 7713-7726. [CrossRef]

35. Bosmans, J.H.C.; van der Ent, R.J.; Haarsma, R.J.; Drijfhout, S.S.; Hilgen, F.J. Precession- and Obliquity-Induced Changes in Moisture Sources for Enhanced Precipitation Over the Mediterranean Sea. Paleoceanogr. Paleoclimatol. 2020, 35, e2019PA003655. [CrossRef]

36. Link, A.; Berger, M.; Van Der Ent, R.; Eisner, S.; Finkbeiner, M. Considering the Fate of Evaporated Water across Basin BoundariesImplications for Water Footprinting. Environ. Sci. Technol. 2021, 55, 10231-10242. [CrossRef]

37. Tuinenburg, O.A.; Theeuwen, J.J.E.; Staal, A. High-resolution global atmospheric moisture connections from evaporation to precipitation. Earth Syst. Sci. Data 2020, 12, 3177-3188. [CrossRef]

38. Van Der Ent, R.J.; Savenije, H.H.G.; Schaefli, B.; Steele-Dunne, S.C. Origin and fate of atmospheric moisture over continents. Water Resour. Res. 2010, 46, W09525. [CrossRef]

39. Link, A.; Van Der Ent, R.; Berger, M.; Eisner, S.; Finkbeiner, M. The fate of land evaporation-A global dataset. PANGAEA 2019, 12, 1897-1912. [CrossRef] 